\title{
HUBUNGAN TINGKAT KECEMASAN DENGAN TERJADINYA INSOMNIA PADA WANITA PREMENOPAUSE DI DUSUN NGABLAK DESA KEDUNGRUKEM KECAMATAN BENJENG KABUPATEN GRESIK
}

\author{
Nur Hidaayah, Hilmi Alif \\ Fakultas Keperawatan dan Kebidanan \\ Universitas Nahdlatul Ulama Surabaya Jl. Smea 57 Surabaya \\ Email : nurhid@unusa.ac.id
}

\begin{abstract}
The anxiety that occurs in premenopausal women causes onset insomnia, due to physical changes. Most premenopausal women are not ready to face those changes, so that if not tackled will continue on depression. The purpose of the research is to find out the relationship with the level of anxiety and insomnia in premenopausal women in Dusun Ngablak Desa Kedungrukem Kecamatan Benjeng Kabupaten Gresik. Analytic design research using the approach of cross sectional. The population was premenopausal women amounted to 80 people, a large sample of the 66 respondents taken with Simple Random Sampling technique. The independent variable and the dependent variable levels of anxiety onset insomnia. The instrument uses a sheet of the questionnaire. The data obtained were tested with Mann-Whitney with a level of significance $(\alpha=0.05)$. The results showed a large majority (56.1\%) experienced a mild anxiety and the majority (68.2\%) experiencing insomnia. Mann-Whitney test results obtained $\rho=0.000$ and $\alpha=0.05$, meaning $\alpha$ then HO $\rho<$ rejected means that there is a relationship with the level of anxiety and insomnia in premenopausal women in Dusun Ngablak Desa Kedungrukem Kecamatan Benjeng Kabupaten Gresik. Most women experience mild anxiety levels of premenopausal and most experienced insomnia. So it's recommended for premenopausal women to think positive on any changes experienced on the body, so that it can reduce anxiety and did not experience insomnia.
\end{abstract}

Keywords: Anxiety, insomnia, premenopausal women

\begin{abstract}
ABSTRAK : Kecemasan yang terjadi pada wanita premenopause menyebabkan terjadinya insomnia, karena adanya perubahan fisik. Kebanyakan wanita premenopause tidak siap menghadapi perubahan-perubahan tersebut, sehingga apabila tidak ditangani akan berlanjut pada depresi. Tujuan penelitian yaitu untuk mengetahui hubungan tingkat kecemasan dengan terjadinya insomnia pada wanita premenopause di Dusun Ngablak Desa Kedungrukem Kecamatan Benjeng Kabupaten Gresik. Desain penelitian analitik dengan menggunakan pendekatan cross sectional. Populasi adalah wanita premenopause berjumlah 80 orang, besar sampel 66 responden diambil dengan teknik Simple Random Sampling. Variabel independen tingkat kecemasan dan variabel dependen terjadinya insomnia. Instrumen menggunakan lembar kuesioner. Data yang diperoleh diuji dengan Mann-Whitney dengan tingkat kemaknaan $(\alpha=0,05)$. Hasil penelitian menunjukkan sebagian besar $(56,1 \%)$ mengalami kecemasan ringan dan sebagian besar $(68,2 \%)$ mengalami insomnia. Hasil uji Mann-Whitney diperoleh $\rho=0,000$ dan $\alpha=0,05$, berarti $\rho<$ $\alpha$ maka $\mathrm{H}_{0}$ ditolak artinya terdapat hubungan tingkat kecemasan dengan terjadinya insomnia pada wanita premenopause di Dusun Ngablak Desa Kedungrukem Kecamatan Benjeng Kabupaten Gresik. Sebagian besar wanita premenopause mengalami tingkat
\end{abstract}


kecemasan ringan dan sebagian besar mengalami insomnia. Peran perawat memberikan pembinaan dan penyuluhan tentang menopause dan cara penanganan dari keluhan yang dirasakan sehingga wanita premenopause tidak mengalami kecemasan.

Kata kunci : Kecemasan, insomnia, wanita premenopause

\section{PENDAHULUAN}

Insomnia merupakan salah satu gangguan tidur, di mana seseorang merasa sulit untuk ingin tidur. Kesulitan tidur ini bisa menyangkut lamanya waktu tidur (kuantitas), atau kelelapan (kualitas) tidur. Insomnia dapat mempengaruhi pekerjaan, aktivitas sosial dan status kesehatan penderitanya (Hediyanti, 2012). Dari sekian banyak penyebab dari insomnia salah satunya diantaranya adalah kecemasan, dimana seseorang merasa gelisah yang mendalam karena memikirkan masalah yang sedang dihadapinya (Putra,S.R, 2011).

Insomnia merupakan salah satu gejala yang dialami oleh wanita premenopause. Premenopause adalah suatu kondisi fisiologis wanita yang telah memasuki rasa penuaan (aging) yaitu wanita yang berusia 40-50 tahun.

Prevalensi gangguan tidur yang terjadi di Amerika mencapai 60-70 kasus orang dewasa. Di Indonesia, prevalensi gangguan tidur sekitar $10 \%$ yang berarti 28 juta orang dari total 238 juta penduduk Indonesia menderita insomnia (Amir, N. 2010). Sedangkan menurut hasil survei pengambilan data awal di Dusun Ngablak Desa Kedungrukem Kecamatan Benjeng Kabupaten Gresik, didapati 6 orang mengalami sulit tidur karena memikirkan hal-hal yang akan terjadi ketika mereka mengalami menopause. Sedangkan 4 orang lainnya tidak mengalami insomnia.

Gejala-gejala psikologis pada masa menopause adalah perasaan murung, kecemasan, irritabilitas dan perasaan yang berubah-ubah, merasa tidak berdaya, gangguan daya ingat, konsentrasi berkurang, sulit mengambil keputusan, merasa tidak berharga (Glasier \& Gebbie, 2006). Sedangkan gejala-gejala fisik yang dapat timbul pada premenopause antara lain semburan rasa panas (hot flushes) dan keringat pada malam hari, kelelahan, gangguan tidur (insomnia), kekeringan kulit dan rambut, sakit dan nyeri pada persendian, sakit kepala, palpitasi (denyut jantung cepat dan tidak teratur), dan berat badan bertambah (Women's Health Concern, 2015).

Kecemasan dapat terjadi pada wanita dan sebagian besar terjadi pada wanita premenopause, ini terjadi karena adanya perubahan fisik yang menjadi masalah yang dihadapi oleh sebagian besar wanita premenopause dan dapat memicu gangguan psikosomatik berupa gangguan tidur, jika tidak ditangani akan berlanjut pada depresi (Struad, G.W. 2006).

Penyebab insomnia meliputi faktor psikologi (stres dan depresi); stres yang berkepanjangan sering menjadi penyebab dari insomnia menjadi kronis, sakit fisik, faktor lingkungan, gaya hidup, usia, jenis kelamin; wanita secara psikologis memiliki mekanisme koping yang lebih rendah dibandingkan dengan laki-laki. Dengan adanya gangguan secara fisik maupun psikologis tersebut maka wanita akan mengalami suatu kecemasan (Suwahadi, 2008; Perry Potter 2006).

Banyak faktor yang mempengaruhi kecemasan, menurut Prof. Dr. Dadang Hawari (2013) mekanisme terjadinya cemas yaitu psiko-neuro-imunologi atau psiko-neuro-endokrinologi. Akan tetapi tidak semua orang yang mengalami stresor psikososial akan menghalami 
gangguan cemas. Hal ini tergantung pada struktur perkembagan kepribadian diri seseorang tersebut yaitu usia, tingkat pendidikan, pengalaman, jenis kelamin, dukungan sosial dari kelurga, teman dan masyarakat.

Berdasarkan uraian di atas, penulis tertarik untuk melakukan penelitian tentang hubungan tingkat kecemasan dengan terjadinya insomnia pada wanita premenopause di Dusun Ngablak Desa Kedungrukem Kecamatan Benjeng Kabupaten Gresik.

\section{METODE PENELITIAN}

Desain penelitian analitik dengan menggunakan pendekatan Cross sectional. Populasi adalah wanita premenopause berjumlah 80 orang, besar sampel 66 responden diambil dengan teknik Simple Random Sampling. Variabel independen tingkat kecemasan, sedangkan variabel dependen terjadinya insomnia. Instrumen menggunakan kuesioner. Data yang diperoleh diuji dengan Mann-Whitney dengan tingkat kemaknaan $(\alpha=0,05)$.

\section{HASIL \& PEMBAHASAN}

a. Hasil

Data Umum

Tabel 1. Distribusi frekuensi responden berdasarkan usia di Dusun Ngablak Kedungrukem Benjeng Gresik

\begin{tabular}{cccc}
\hline No & $\begin{array}{c}\text { Usia } \\
\text { (tahun) }\end{array}$ & Frekuensi & $\begin{array}{c}\text { Persentase } \\
(\%)\end{array}$ \\
\hline 1 & $40-45$ & 26 & 39,4 \\
2 & $46-50$ & 40 & 60,6 \\
\hline & Jumlah & 66 & 100 \\
\hline
\end{tabular}

Tabel 1 dapat diketahui dari 66 responden sebagian besar $(60,6 \%)$ berusia 46-50 tahun.

Tabel 2. Distribusi frekuensi responden berdasarkan pekerjaan di
Dusun Ngablak Kedungrukem Benjeng Gresik

\begin{tabular}{clcc}
\hline No & Pekerjaan & Frekuensi & $\begin{array}{c}\text { Persentase } \\
(\%)\end{array}$ \\
\hline 1 & Bekerja & 31 & 47,0 \\
2 & $\begin{array}{l}\text { Tidak } \\
\text { bekerja }\end{array}$ & 35 & 53,0 \\
\hline & Jumlah & 66 & 100 \\
\hline
\end{tabular}

Tabel 2 dapat diketahui dari 66 responden $(53,0 \%)$ wanita premenopause Di Dusun Ngablak tidak bekerja.

Tabel 31. Distribusi frekuensi responden berdasarkan pendidikan di Dusun Ngablak Kedungrukem Benjeng Gresik

No Pendidikan Frekuensi Persentase

\begin{tabular}{cccc}
\hline 1 & Dasar & 49 & 74,2 \\
2 & Menengah & 16 & 24,2 \\
3 & Tinggi & 1 & 1,5 \\
\hline & Jumlah & 66 & 100
\end{tabular}

Tabel 3 dapat diketahui dari 66 responden $(74,2 \%)$ merupakan tingkat pendidikan dasar.

\section{Data Khusus}

Tabel 4. Distribusi frekuensi responden berdasarkan tingkat kecemasan di Dusun Ngablak Kedungrukem Benjeng Gresik

\begin{tabular}{cccc}
\hline No & $\begin{array}{c}\text { Tingkat } \\
\text { Kecemasan }\end{array}$ & $\begin{array}{c}\text { Frekuen } \\
\text { si }\end{array}$ & $\begin{array}{c}\text { Persentase } \\
(\%)\end{array}$ \\
\hline 1 & Ringan & 37 & 56,1 \\
2 & Sedang & 15 & 22,7 \\
3 & Berat & 0 & 0 \\
4 & Panik & 0 & 0 \\
5 & Tidak ada & 14 & 21,2 \\
\hline & Jumlah & 66 & 100 \\
\hline
\end{tabular}

Tabel 4 dapat diketahui dari 66 responden sebagian besar $(56,1 \%)$ mengalami kecemasan ringan. 
Tabel 5. Distribusi frekuensi responden berdasarkan kejadian insomnia di Dusun Ngablak Kedungrukem Benjeng Gresik

mengalami tingkat kecemasan ringan. Hal ini menunjukkan bahwa tingkat kecemasan yang dialami oleh wanita premenopause di Dusun Ngablak Desa Kedungrukem Kecamatan Benjeng \begin{tabular}{llll}
\hline No & Terjadinya & Frekuensi & Persentase Kabupaten Gresik rata-rata 1,85
\end{tabular} $\begin{array}{llll} & & (\%) & \text { mengalami perasaan cemas, seperti takut }\end{array}$ 2 Tidak insomnia $21 \quad 31,8$ premenopause di Dusun Ngablak 1,91 Jumlah $\quad 66 \quad 100$ sering terbangun pada malam hari.

Kebanyakan wanita premenopause

Tabel 5 dapat diketahui dari 66 responden sebagian besar $(68,2 \%)$ mengalami insomnia.

Tabel 6. Tabulasi silang hubungan tingkat kecemasan dengan kejadian insomnia di Dusun Ngablak Kedungrukem Benjeng Gresik

\begin{tabular}{ccc}
\hline & Insomnia & \\
\hline Tingkat Kecemasan & Insomnia & $\begin{array}{c}\text { Tidak } \\
\text { Insomnia }\end{array}$ \\
\hline & $\mathrm{N} \%$ & $\mathrm{~N} \%$
\end{tabular}

\begin{tabular}{lcccc} 
Ringan & 29 & 78,4 & 8 & 21,6 \\
Sedang & 14 & 93,3 & 1 & 6,6 \\
Berat & 0 & 0 & 0 & 0 \\
Panik & 0 & 0 & 0 & 0 \\
Tidak ada kecemasan & 2 & 14,2 & 12 & 85,7 \\
\hline Jumlah & 45 & 68,2 & 21 & 31,8 \\
\hline
\end{tabular}

Tabel 6 di atas menunjukkan bahwa dari 66 responden, 37 responden yang mengalami kecemasan ringan hampir seluruhnya $(78,4 \%)$ mengalami insomnia, 15 responden mengalami kecemasan sedang hampir seluruhnya $(93,3 \%)$ mengalami insomnia, sedangkan 14 responden tidak ada kecemasan $(85,7 \%)$ tidak mengalami insomnia.

\section{b. Pembahasan}

\section{Tingkat Kecemasan}

Hasil penelitian berdasarkan tabel 4 dari 66 responden sebagian besar $(56,1 \%)$ cemas dan takut akan masa menopause, karena mereka beranggapan sudah memasuki usia tua dan kebanyakan dari mereka ada yang masih belum bisa menerima dengan lapang dada.

Kecemasan adalah kekhawatiran yang tidak jelas dan menyebar dan berkaitan dengan perasaan yang tidak pasti dan tidak berdaya. Pada hasil penelitian didapatkan yang paling banyak responden alami adalah kategori Total individu untuk berfokus pada hal yang penting dan mengesampingkan hal lain. 3RedOhasan ini mempersempit persepsi 15ndibigu (Stuard, G.W. 2006).

Pada wanita premenopause kecemasan ringan umumnya masih onanopu berfikir jernih dan rasional dalam 14pabog mencari pemecahan penyebab timbulnya kecemasan yang dihadapi. 66edemasan ringan merupakan tingkat kecemasan yang umum dialami wanita premenopause. Biasanya kecemasan sering muncul seiring dengan pertambahan usia, dimana kondisi fisik maupun psikis mulai mengalami penuaan.

Faktor yang mempengaruhi terjadinya kecemasan pada wanita premenopause menurut Hurlock yang dikutip oleh Nursalam (2013) yaitu usia, lingkungan, pendidikan, pengetahuan, status ekonomi, dan dukungan keluarga. Berdasarkan tabel 1 diketahui bahwa dari 66 responden sebagian besar $(60,6 \%)$ berusia 46-50 tahun. Pada usia tersebut 
saat dimana seorang wanita akan berada dalam periode premenopause dimana gejala dan keluhan menopause akan muncul. Sehingga pada usia tersebut sering timbul kecemasan akibat perubahan yang terjadi pada tubuh.

Pada tabel 3 diketahui bahwa dari 66 responden $(74,2 \%)$ pendidikan terakhirnya adalah tingkat dasar. Diharapkan semakin tinggi tingkat pendidikan seseorang maka semakin banyak pengetahuan yang dimiliki dan semakin mempermudah proses penerimaan informasi. Sehingga kecemasan menjelang menopause dapat diatasi dengan baik (Aprilia, N.I \& Puspitasari,N. 2007).

Gejala-gejala psikologis pada masa menopause adalah perasaan murung, kecemasan, irritabilitas dan perasaan yang berubah-ubah, merasa tidak berdaya, gangguan daya ingat, konsentrasi berkurang, sulit mengambil keputusan, merasa tidak berharga (Glasier \& Gebbie, 2006). Sedangkan gejala-gejala fisik yang dapat timbul pada premenopause antara lain semburan rasa panas (hot flushes) dan keringat pada malam hari, kelelahan, gangguan tidur (insomnia), kekeringan kulit dan rambut, sakit dan nyeri pada persendian, sakit kepala, palpitasi (denyut jantung cepat dan tidak teratur), dan berat badan bertambah (Women's Health Concern, 2015).

\section{Terjadinya Insomnia}

Hasil penelitian berdasarkan tabel 5 dari 66 responden $(68,2 \%)$ mengalami insomnia. Hal ini menunjukkan bahwa insomnia merupakan salah satu gejala yang dialami oleh wanita premenopause. Sebagian besar wanita premenopause rata-rata 3,21 susah untuk memulai tidur, mereka membutuhkan waktu untuk memulai tidur sekitar 45-60 menit. Selain itu kebanyakan wanita premenopause 2,46 tidur nyenyak, tetapi mudah untuk terbangun.
Wanita yang semakin tua mendapatkan menopause maka akan meningkatkan faktor risiko terjadinya insomnia. Umur seseorang berbanding lurus dengan meningkatnya gangguan tidur yang sifatnya temporer atau menetap, dimana prevalensi insomnia meningkat dengan bertambahnya usia. Selain itu, faktor lingkungan yang kurang mendukung suasana tidur bisa berupa tempat tidur yang nyaman, kamar tidur terlalu terang atau berisik, iklim yang terlalu panas, dan sebagainya.

Insomnia merupakan salah satu gangguan tidur, di mana seseorang merasa sulit untuk ingin tidur. Kesulitan tidur ini bisa menyangkut lamanya waktu tidur (kuantitas), atau kelelapan (kualitas) tidur. Insomnia merupakan gejala awal dalam masalah tidur yang berkaitan dengan masalah fisik, mental, atau emosi (Durand \& Barlow, 2007).

Insomnia dapat mempengaruhi pekerjaan, aktivitas sosial dan status kesehatan penderitanya. Berdasarkan tabel 2 dapat diketahui bahwa dari 66 responden $(53,0 \%)$ wanita premenopause Di Dusun Ngablak tidak bekerja. Dampak pada kesehatan di antaranya menyebabkan penambahan berat badan, daya tahan tubuh menjadi lemah sehingga mudah sakit, stress meningkat (Hediyanti, 2012).

Penyebab insomnia meliputi faktor psikologi (stres dan depresi); stres yang berkepanjangan sering menjadi penyebab dari insomnia menjadi kronis, sakit fisik, faktor lingkungan, gaya hidup, usia, jenis kelamin; wanita secara psikologis memiliki mekanisme koping yang lebih rendah dibandingkan dengan laki-laki. Dengan adanya gangguan secara fisik maupun psikologis tersebut maka wanita akan mengalami suatu kecemasan (Suwahadi, 2008; Perry Potter 2006).

Dari sekian banyak penyebab dari insomnia salah satunya diantaranya adalah kecemasan, dimana seseorang merasa gelisah yang mendalam karena 
memikirkan masalah yang sedang dihadapinya (Putra, S.R. 2011).

\section{Hubungan Tingkat Kecemasan Dengan Terjadinya Insomnia Pada Wanita Premenopause}

Hasil penelitian tersebut membuktikan bahwa tingkat kecemasan berhubungan secara signifikan dengan kejadian kecemasan pada wanita premenopause. Artinya, apabila tingkat kecemasan yang dialami semakin berat, maka kejadian insomnia pada wanita premenopause juga semakin buruk, begitu pula sebaliknya.

Hal tersebut juga bisa dilihat dari hasil tabulasi silang bahwa dari 11 responden yang tidak ada kecemasan, didapatkan (91,7\%) tidak insomnia. Kemudian dari 29 responden yang mengalami tingkat kecemasan ringan, didapatkan $(76,3 \%)$ mengalami insomnia. Sedangkan dari 15 responden yang mengalami tingkat kecemasan sedang, didapatkan $(93,7 \%)$ mengalami insomnia.

Faktor yang mempengaruhi insomnia yaitu faktor fisik, faktor lingkungan, gaya hidup, dan faktor psikologis. Pada wanita premenopause yaitu berusia sekitar 40-50 tahun ke atas, salah satu gejala pada masa premenopause adalah susah tidur (insomnia). Hal ini akan membuat mereka menjadi susah tidur di malam hari, atau jika terbangun di malam hari mereka akan sulit untuk mendapatkan tidur mereka kembali. Insomnia dapat terjadi sebagai reaksi simptom yang sederhana atau mungkin berkaitan dengan kondisi-kondisi psikiatrik lain seperti kecemasan (Adeleyna, N. 2008).

Kecemasan dapat terjadi pada wanita premenopause, ini terjadi karena adanya perubahan fisik yang menjadi masalah yang dihadapi oleh sebagian besar wanita jika tidak ditangani akan berlanjut pada depresi (Struad, G.W. 2006).
Sebenarnya tingkat kecemasan yang dialami oleh wanita premenopause di Dusun Ngablak Desa Kedungrukem Kecamatan Benjeng Kabupaten Gresik masuk dalam kategori ringan, namun berhubung yang mengalami adalah orang yang sudah mempunyai potensi insomnia, sehingga masyarakat tidak boleh menganggap remeh insomnia, karena apabila dibiarkan insomnia semakin bertambah buruk. Hal ini sesuai dengan pendapat Widya (2010) kasus insomnia akibat situasi stres atau kecemasan menyebabkan kesulitan kronik untuk mendapatkan tidur cukup.

Upaya mengatasi insomnia pada wanita premenopause harus diatasi faktor penyebab utamanya terlebih dahulu. Apabila yang menjadi penyebab adalah faktor fisik, maka harus ditangani dengan tindakan medis. Namun apabila penyebabnya adalah faktor psikologis seperti kecemasan, cara untuk mengurangi kecemasan yaitu dengan berpikir positif pada setiap perubahan yang dialami pada tubuh, meningkatkan aktifitas sehari-hari agar dapat mengalihkan stressor yang dapat menyebabkan kecemasan, selain itu juga harus dilakukan pendekatan secara persuasif untuk membantu menyelesaikan permasalahannya.

\section{SIMPULAN DAN SARAN}

\section{Simpulan}

1. Wanita premenopause di Dusun Ngablak Desa Kedungrukem Kecamatan Benjeng Kabupaten Gresik sebagian besar mengalami tingkat kecemasan ringan.

2. Wanita premenopause di Dusun Ngablak Desa Kedungrukem Kecamatan Benjeng Kabupaten Gresik sebagian besar mengalami insomnia.

3. Ada hubungan tingkat kecemasan dengan terjadinya insomnia pada 
wanita premenopause di Dusun Ngablak Desa Kedungrukem Kecamatan Benjeng Kabupaten Gresik.

\section{Saran}

1. Bagi Institusi

Hasil penelitian ini diharapkan dapatmenjadi bahan acuan referensi pustaka yang terkait dengan tingkat kecemasan dan terjadinya insomnia pada wanita premenopause.

\section{Bagi Responden}

Hendaknya responden banyak meluangkan waktu untuk rekreasi sehingga tidak terjadi kecemasan yang berdampak gangguan tidur (Insomnia)

3. Bagi Peneliti Selanjutnya

Menggunakan metode dan instrument yang berbeda tentang kecemasan dan gangguan insomnia pada wanita premenopause. Penting pula melakukan pengukuran yang lebih mendalam baik dari sisi fisiologis, psikis, biologis, dan juga faktor eksternal keadaan disekitar responden.

4. Bagi Masyarakat

Pentingnya peran para kader kesehatan melakukan program penyuluhan bagi wanita premenopause khususnya dibidang kesehatan.

\section{DAFTAR PUSTAKA}

Adeleyna, N. (2008). Analisis Insomnia Pada Mahasiswa Melalui Model Pengaruh Kecemasan Tes. www.lib.ui.ac.id. Diakses pada 13 Februari 2016

Aprilia, N.I., Puspitasari, N., 2007. Faktor yang Mempengaruhi Tingkat Kecemasan pada Wanita Perimenopause, Surabaya: The
Indonesian Journal of Public Health, Vol. 4, No. 1.

Amir, N (2010). Tata Laksana Insomnia - Insomnia Bisa Terjadi Pada Semua Lapisan Usia, Tak Terkecuali Anak-Anak. Jakarta

Durand and Barlow (2007). Intisari Psikologi Abnormal. Buku kedua. Penerjemah : Soedjipto. Penerbit : Pustaka Pelajar. Jakarta.

Glasier \& Gebbie (2006). Keluarga Berencana dan Kesehatan Reproduksi. Edisi 4. Penerbit Buku Kedokteran EGC. Jakarta.

Hawari, Dadang (2013). Manajemen Stres Cemas dan Depresi. Jakarta, Balai Penerbit FKUI

Hurlock, E. B (2007). Psikologi Perkembangan Edisi Kelima. Jakarta, Erlangga.

Nursalam (2011). Konsep dan Penerapan Metodologi Penelitian Ilmu Keperawatan Edisi 2. Jakarta, Salemba Medika.

Putra, S. R. (2011). Tips Sehat Dengan Pola Tidur Yang Tepat Dan Cerdas. Yogyakarta: Buku Biru.

Struad, G.W. (2006). Buku Saku Keperawatan Jiwa. Jakarta: EGC

Suwahadi. (2008). Pengertian dan Faktor dari Insomnia. http:// jurnalinsomnia.org. Diakses pada tanggal 14 Februari 2016.

Widya (2010).Pengaruh Pemberian Senam Yoga Untuk Mengurangi Insomnia Pada Lansia. Naskah Publikasi. eprints.ums.ac.id/41122/18/NASK 
AH\%20PUBLIKASI.pdf. Diakses tanggal 12 Februari 2016.

Women's Health Concern (2015). Menopause: Giving you confidence for understanding and action. https://www. womens-healthconcern.org/. Diakses tanggal 12 februari 2016. 